\title{
ANALISIS PENENTUAN MODEL MERGER-AKUISISI YANG SINERGIS DI BURSA EFEK INDONESIA
}

\author{
Muhamad Umar Mai \\ Prodi Keuangan dan Perbankan Politeknik Negeri Bandung \\ Jl. Geger Kalong Hilir Ds. Ciwaruga. Bandung, 40012 - Indonesia
}

\begin{abstract}
The aim of this study was as follow: a) to examine the differences in financial performance and the value of the firm before and after the merger-acquisition of go public companies in Indonesia Stock Exchange for the period of 2000-2012;b) to identify and analyze the critical success factors of mergers-acquisitions; c) designing a model of synergistic merger-acquisition. Wilcoxon signed ranks test results showed that the financial performance and the value of the company for certain years are different, in the sense of increased, significantly. The determinant factors of successfull merger-acquisition of 30 synergistic firms, are: a) current ratio and cash ratio was below the industry average; $b$ ) debt to asset ratio and debt to equity ratio is above the industry average; $c$ ) return on investment and return on equity also above the industry average. Analysis of the 30 synergisticbidders firm shows that the company has a very adequate corporate governance mechanism, namely: a) more than $50 \%$ of its stocks owned by other institutions; $b$ ) the shares held by the management is below $5 \%$; c) the membership of the board of commissioners and directors have an independent boards and outside directors of more than $30 \%$; and d) the average number of commissioners as many as six people.
\end{abstract}

Keywords: mergers-acquisitions, financial performance, the value of the firm, and corporate governance mechanism.

\section{PENDAHULUAN}

Tujuan berdirinya perusahaan adalah untuk memaksimumkan nilai perusaha-an yang tercermin dari meningkatnya harga saham di pasar modal(Akinbuli dan Kelilume, 2013). Pencapaian tujuan ini semakin kompleks dan sulit, karena dunia usaha telah memasuki era dimana terjadi kemajuan yang sangat pesat dibidang komunikasi, teknologi dan informasi. Ini menyebabkan terjadinya arus perpindahan berbagai sumber daya keluar dari batas-batas suatu negara,dan perkembangan per-ekonomian dunia telah bergerak ke arah perdagangan bebas (Idrus dan Irma, 2010).

Salah satu strategi yang dapat ditempuh untuk mempertahankan dan mengembangkan perusahaan adalah dengan melakukan penggabungan usaha

Korespondensi dengan Penulis:

Muhamad Umar Mai. HP: +6281220357210

e-mail: umar.mai@polban.ac.id 
(Idrus dan Irma, 2010). Mengacu pada kondisi perekonomian dunia saat inimerger-akuisisi diprediksi dapat menciptakan momentum pertumbuhan dan upaya mengefisienkan biaya melalui pengurangan kelebihan kapasitas yang pada gilirannya akan meningkatkan profitabilitas dan nilai perusahaan (Brealeyet al. 2010; dan Azeem, 2011). Merger-akuisisi pernah menjadi fenomenabisnis di AS, dan lima tahun terakhir ini gelombang mergerakuisisi tersebar ke seluruh dunia. Merger-akuisisi saat ini digunakan untuk mengembangkan ekonomi, terutama diAsia (Kayani et al., 2013).

Sejak berlakunya Peraturan Komisi Pengawas Persaingan Usaha Nomor 1 Tahun 2009 tentang Pra-Notifikasi Penggabungan, Peleburan dan Pengambilalihan, Komisi Pengawas Persaingan Usaha (KPPU) telah mencatat puluhan notifikasi merger-akuisisi (Nurviani, 2014).Tahun 2010-2012 merupakan tahun-tahun dimana gelombang mergerakuisisi melanda Indonesia, jumlah notifikasi mengalir sangat deras, dan diprediksi akan terus meningkat di masa yang akan datang (Nurviani, 2014). Namun demikian, beberapa penelitian sebelumnya yang dilakukan terhadap capaian kinerja keuangan dari perusahaan-perusahaan yang menjalankan merger-akuisisi menemukan bukti yang saling bertentangan. Disajikan pada Tabel 1berikut:

Berdasarkan pada fenomena semakin meningkatnya aktivitas merger-akuisisi baik di luar negeri maupun di Indonesia,dan adanya kontradiksi hasil penelitian tentang kinerja perusahaan sebelum dan sesudah merger-akuisisi. Penelitian ini bertujuan untuk: 1).Membandingkan kembali kinerja keuangan dan nilai perusahaan sebelum dan sesudah merger-akuisisi; 2). Menganalisis faktor-faktor yang menen-tukan keberhasilan merger-akuisisi yang dijalankan perusahaan; dan 3).Merancang serta mengusulkan suatu model merger-akuisisi yang dapat menciptakan sinergis.

TABEL 1: Research Gap Kinerja KeuanganSebelum dan Sesudah Merger-Akuisisi

\begin{tabular}{|c|c|c|c|}
\hline Gap & Hasil & Peneliti & Variabel Penelitian \\
\hline \multirow{3}{*}{$\begin{array}{l}\text { Terdapat } \\
\text { perbedaan } \\
\text { temuan hasil } \\
\text { penelitian } \\
\text { tentang; Kinerja } \\
\text { Keuangan } \\
\text { Perusahaan } \\
\text { Sebelum dan } \\
\text { Sesudah Merger } \\
\text { dan Akuisisi }\end{array}$} & $\begin{array}{l}\text { Menemukan bukti } \\
\text { adanya kenaikkan } \\
\text { kinerja keuangan } \\
\text { perusahaan. }\end{array}$ & $\begin{array}{l}\text { - Chuang dan Lee (2011) } \\
\text { - Raniet al. (2013) } \\
\text { - Kumara dan Satya-Narayana } \\
\text { (2013). }\end{array}$ & $\begin{array}{l}\text { - Operating capability, } \\
\text { Pofitability, dan Financial } \\
\text { structure. } \\
\text { - Struktur Modal, Laba } \\
\text { Operasinal, EPS dan Debt } \\
\text { Equity Ratio. } \\
\text { - Current Ratio, Quick Ratio, } \\
\text { DARdan ROI. }\end{array}$ \\
\hline & $\begin{array}{l}\text { Menemukan bukti } \\
\text { tidak ada perubahan } \\
\text { kinerja keuangan } \\
\text { perusahaan. }\end{array}$ & $\begin{array}{l}\text { - Akinbuli dan Kelilume (2013) } \\
\text { - Trivediet al. (2013) } \\
\text {-Weberet al. (2011) }\end{array}$ & $\begin{array}{l}\text { - Profitability } \\
\text { Ratio,Liquidity Ratio, dan } \\
\text { Capital Adequacy. } \\
\text { - Return on Asset, ROE, } \\
\text { NPM, Debt to Equity Ratio. } \\
\text { - Budaya Nasional dan } \\
\text { Perusahaan, Potensi } \\
\text { Kinerja Perusahaan. }\end{array}$ \\
\hline & $\begin{array}{l}\text { Menemukan bukti } \\
\text { adanya penurunan } \\
\text { kinerja keuangan } \\
\text { perusahaan. }\end{array}$ & $\begin{array}{l}\text { - Shukla dan Gekara (2010). } \\
\text { - Kayaniet al. (2013) }\end{array}$ & $\begin{array}{l}\text { - Net Operating Profit After } \\
\text { Tax, Return On Asset, EPS, } \\
\text { etc. } \\
\text { - Return on Assets, ROE, } \\
\text { Debt to Equity Ratio, etc. }\end{array}$ \\
\hline
\end{tabular}

Sumber: hasil-hasil penelitian sebelum yang dirangkum 


\section{Jurnal Keuangan dan Perbankan | KEUANGAN}

Vol. 20, No.3, September 2016: 382- 394

Berdasarkan pada uraian pendahuluan di atas, Gambar 2 di bawah ini menyajikan diagram alur sebagai kerangka pemikiran dari penelitian ini.

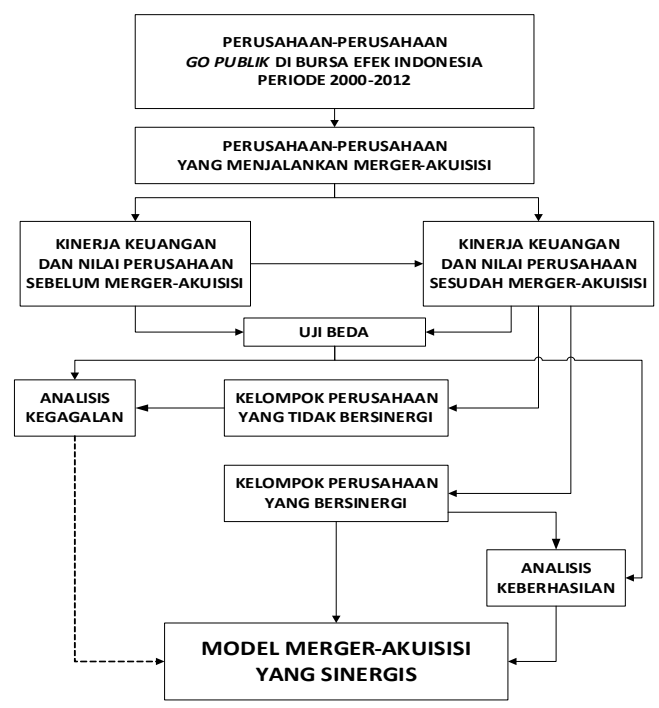

Gambar 2: Alur Diagram Kerangka Pemikiran Sumber: Dikembangkan untuk penelitian ini

\section{Penggabungan Usaha}

Penggabungan usaha terbagi menjadi merger, akuisisi dan konsolidasi.Moin (2010) mendefinisikan merger adalah penggabungan dua atau lebih perusahaan, kemudian hanya ada satu perusahaan yang tetap hidup sebagai badan hukum. Evaruth (2010) menjelaskan bahwa akuisisi adalah penggabungan usaha dimana salah satu perusahaan, yaitu pengakuisisi (acquirer) memperoleh kendali atas aktiva netto dan operasi perusahan yang diakuisisi (acquiree). Konsolidasi adalah pengga-bungan usaha yang dilakukan dengan mengalihkan aktiva dan kewajiban perusa-haan yang bergabung dengan cara membentuk perusahaan baru (Widodo, 2012).

\section{Motif Merger dan Akuisisi}

Pada prinsipnya ada dua motif yang mendorong perusahaan menjalankan merger-akuisisi yaitu motif ekonomi dan motif non ekonomi. Motif ekonomi berkaitan dengan tujuan perusahaan yaitu memaksimumkan nilai perusahaan. Motif non ekonomi adalah motif yang didasarkan pada keinginan subyektif atau ambisi pribadi dari pihak pemilik atau dari pihak manajemen perusahaan (Moin, 2010).

Moin (2010) menjelaskan manfaat mergerakuisisi adalah: 1) mendapatkan cash flowyang cepat karena produk, pasardan pelanggan sudah jelas sehingga dapat mengurangi risiko gagal bisnis; 2) menghemat waktu bagi perusahaan untuk memasuki bisnis baru;3) memperoleh kemudahan dana karena kreditor lebih percaya pada perusahaan yang telah berdiri. Kelemahan merger-akuisisi diantaranya: 1) proses integrasi tidak mudah, karena sulit untuk menentukan nilai perusahaan target secara akurat; 2) biaya konsultan dan koordinasi yang sangat mahal.

Berdasarkan pada uraian di atas dapat dipahami bahwa faktor keberhasilan dan gagalnya merger-akuisisi lebih ditentukan oleh kinerja keuangan, yang pada gilirannya akan berdampak pada capaian nilai perusahaan. Dengan demikian dapat dirumuskan hipotesisyang pertama, yaitu sebagai berikut:

H-1.1 : Capaian kinerja keuangan lebih sering berbeda secara singnifikan setelah perusahaan menjalankan program merger-akuisisi;

H-1.2 : Capaian nilai perusahaan lebih sering berbeda secara singnifikan setelah perusahaan menjalankan program merger-akuisisi.

\section{Faktor Penentu Keberhasilan Merger-Akuisisi}

Hitt (2002) dalam Wijaya (2013)menjelaskan bahwa konsep penting yang mengarah pada keberhasilan atau gagalanya merger-akuisisi adalah due diligance, pembiayaan, sumber daya komplementer, akuisisi bersahabat atau tidak bersahabat, penciptaan sinergi pembelajaran organisasional dan fokus pada bisnis inti. 


\section{Analisis Penentuan Model Merger-Akuisisi yang Sinergis di Bursa Efek Indonesia}

Muhamad Umar Mai

\section{Mekanisme Corporate Governance}

Haatetal. (2008) dalam Lukas dan Basuki (2014) mendefinisikan corporate governance sebagai seperangkat mekanisme yang akan melindungi para investor terhadap aksi berbahaya atau merugikan yang dilakukan pihak manajemen perusahaan terhadap modal yang telah mereka(para investor) investasikan.

Sejalan dengan Argüden (2013), prinsip Good Corporate Governance (GCG) yang tercantum pada pedoman umum GCG Indonesia adalah transparency; accountability; responsibility; independency; dan fairness. Penerapan GCG diyakini dapat menciptakan iklim yang kondusif dan landasan yang kokoh untuk menjalankan operasional perusahaan (Amanti, 2012).Kualitas mekanisme corporate governance yang dimiliki perusahaan mendorong capaian kinerja keuangan yang tinggi, dan pada gilirannya akan menjamin keberhasilan mergerakuisisi yang dilakukan perusahaan.

Berdasarkan pada uraian di atas, maka dapat dirumuskan hipotesiskedua dan hipotesis ketiga, yaitu sebagaiberikut:

H-2 : Kinerja keuangan perusahaan merupakan faktor penentu keberhasilan merger-akuisisi yang dijalankan perusahaan;

H-3 : Mekanisme corporate governance yang dimiliki suatu perusahaan merupakan faktor penentu keberhasilan dari program merger-akuisisi yang dijalankan perusahaan.

\section{METODE}

\section{Populasi dan Sampel}

Populasi penelitian ini adalah seluruh perusahaan go publicdi Bursa Efek Indonesia tahun 20002012. Penentuan sampel menggunakan purposive sampling dengan kriteria: 1)perusahaan menjalankan merger-kuisisi; 2)perusahaan memiliki laporan keuangan 1 dan 2 tahun sebelum dan sesudah menjalankanmerger-akuisisi.

\section{Teknik Analisis Data}

1) Wilcoxon signed ranks test digunakan untuk membandingkan kinerja keuangan dan nilai perusahaan, sebelum dan sesudah mergerakuisisi yang dijalankan. Adapun rumus yang digunakan (Rangkuti, 2012) adalah sebagai berikut:

$$
Z_{o}=\frac{J-\mu_{j}}{\sigma_{j}} \text {, dengan: } \mu_{j}=\frac{n(n+1)}{4} \sigma_{j}=\sqrt{\frac{n(n+1)(2 n+1)}{24}}
$$

Dimana:

$Z_{o}=$ Skala $Z$ observasi/hitung $J=$ Jumlah jenjang/rangking yang kecil

$\mu_{j}=$ Rataan jenjang/rangking $\sigma_{j}=$ Simpangan baku jenjang/rangking

Langkah penggunaan: a)Menentukan $\alpha=5 \%$; b) Jika z output<z table dan $p$-value $>\alpha$, tidak ada perbedaan rasio keuangan dan nilai perusahaan. Jadi, $\mathrm{H}_{0}$ diterima atau Hi ditolak; c) Jika z output $>\mathrm{z}$ table dan $p$-value $<\alpha$, ada perbedaan rasio keuangan dan nilai perusahaan, maka $\mathrm{H}_{0}$ ditolak yang berarti Hi diterima.

2) Analisis faktor-faktor penentu keberhasilan merger-akuisisi menggunakan test hipotesis untuk satu nilai rata-rata. Duakomponen sebagai faktor penentu keberhasilan merger-akuisisi dijadikan dasar evaluasi, yaitu: 1). Kondisikeuangan yang terdiri dari: rasio likuiditas; profitabilitas; dan solvabilitas. 2). Mekanisme corporate governanceyang terdiri dari: rata-rata ukuran dewan komisaris (board size); proporsi boardindependent; institutional ownership; dan managerial ownership.

Test hipotesis untuk satu nilai rata-rata dikerjakan secara manual dengan menggunakan rumus sebagai berikut:

$t_{0}=\frac{\bar{x}-u}{\frac{s}{\sqrt{n}}}$ 


\section{Jurnal Keuangan dan Perbankan | KEUANGAN}

Vol. 20, No.3, September 2016: 382- 394

Dimana: $\bar{x}=$ rata-rata sampel; $\mu=$ rata-rata populasi; $\mathrm{s}=$ standar deviasi sampel; dan $\mathrm{n}=$ jumlah anggota sampel.

Kondisi kinerja keuangan dan kualitas mekanisme corporate overnancedari peru-sahaan-perusahaan yang berhasil menjalankan merger-akuisisi, untuk 1 dan 2 tahun sebelum merger-akuisisi, dibanding dengan standar industri, teori, hasil penelitian sebelumnya serta peraturan yang berlaku. Standar industri untuk kinerja keuangan yang digunakan akan mengacu pada Kasmir (2008). Disajikan pada Tabel 2berikut:

Kualitas mekanisme corporate governance dievaluasi menggunakan standar beri-kut: 1)Board independent, mengacu pada keputusan Direksi PT Bursa Efek Jakarta No. Kep-339/BEJ/07-2001 butir $\mathrm{C}$ tentang boards governance. Keputusan tersebut menya-takan bahwa untuk mencapai good corporate governance maka jumlah anggota dewan komisaris dan atau dewan direksi independen sekurangkurangnya $30 \%$; 2).Ukuran board of commissioners mengacu pada temuan Grag (2007) yang menyatakan bahwa ukuran dewan komisaris yang optimal adalah sekitar 6 orang; 3 ). Besarnya proporsi managerial ownership mengacu pada temuan Morck et al. (1989) dalam Pakaryaningsih (2008) yang menyatakan bahwa hubungan positif antara kepemilikan manajerial dan kinerja keuangan akan terjadi pada level $0 \%-5 \%$; 4). Besarnya proporsi institusional ownership mengacu pada penjelasan agency theoryyaitu bahwaagency problem dapat diatasi dengan meningkatkan monitoring melalui institutional ownership. Institutional ownership yang mencapai paling sedikit 50\% menunjukkan kekuatan pemilik dalam memonitor manajemen (Bathala, et al., 1994; dalam Darmono dan Bachtiar, 2015).

Pengujian akan dilakukan dengan menggunakan taraf nyata $(\alpha)$ sebesar $5 \%$ dan bentuk pengujian dua ujung yaitu ujung kiri dan kanan. Dengan demikian, dapat ditentukan daerah penerimaan dan penolakan Hipotessis nol $\left(\mathrm{H}_{0}\right)$ sebagai berikut:

1). Ho diterima apabila: $-2,0,45 \leq$ to $\leq+2,045$, berarti kinerja keuangan perusahaan dan mekanisme corporate governance sama (tidak berbeda signifikan) dengan standar industri, teori, hasil penelitian sebelumnya dan peraturan yang berlaku.

2), $\mathrm{H}_{0}$ ditolak apabila: to $>+2,045$ atau to $<-2,045$, berarti capaian kinerja keuangan perusahaan dan mekanisme corporate governance berbeda secara signifikan dengan standar industri, teori, hasil penelitian sebelumnya dan peraturan yang berlaku.

\section{Operasionalisasi Variabel Penelitian}

\section{Rasio Likuiditas}

Rasio likuiditas yang digunakan adalah Current Ratio (CRR) dan Cash Ratio (CHR). Digunakan oleh Kumara dan Satyanarayana (2013); Akinbuli dan Kelilume (2013); dan Trivediet al. (2013), dengan rumus sebagai berikut:

$\mathrm{CRR}=\frac{\text { Current } \text { Ratio }}{\text { Current Liabilities }} \mathrm{CHR}=\frac{\text { Current Asset }- \text { Inventory }}{\text { Current Liabilities }}$

\section{Rasio Profitablitas}

Rasio profitablitas menggunakan Return on Investment (ROI) dan Return on Equity (ROE), telah

Tabel 2: Standar Industri Rasio Keuangan

\begin{tabular}{lclc}
\hline \multicolumn{1}{c}{ JENIS RASIO } & STANDAR INDUSTRI & \multicolumn{1}{c}{ JENIS RASIO } & STANDAR INDUSTRI \\
\hline Current Ratio & $200 \%$ & Debt to Equity Ratio & $90 \%$ \\
Cash Ratio & $50 \%$ & Return on Invesment & $30 \%$ \\
Debt to Asset Ratio & $35 \%$ & Return on Equity & $40 \%$ \\
\hline Sumber: Kasmir (2008) & & &
\end{tabular}


digunakan oleh: Chuang dan Lee (2010); Akinbuli dan Kelilume (2013); dan Trivediet al. (2013). Berikut rumus kedua rasio ini:

$$
\mathrm{ROI}=\frac{\text { Net Income }}{\text { Total Asset }} \mathrm{ROE}=\frac{\text { Net Income }}{\text { Total Equity }}
$$

\section{Rasio Leverage}

Rasio leverage menggunakan Debt to Total Equity Ratio (DER) dan Debt to Total Asset Ratio (DAR), telah digunakan oleh: Rani et al. (2013); Kumara dan Satyanarayana (2013); dan Kayani et al. (2013). Rumus kedua rasio ini adalah:

DER = Total Debt $/$ Total Equity;

DAR $=$ Total Debt $/$ Total Asset

\section{Rasio Pasar}

Rasio pasarakan menggunakan Price Earnings Ratio (PER) dan Price to Book Ratio (PBV). Sebagaimana telah digunakan oleh penelitian sebelumnya, yaitu: Syanas (2008) dan Stella (2009). Rumus dari kedua rasio ini adalah sebagai berikut: PER = Share Price/Earnings Per Share; $\mathrm{PBV}=$ Share Price $/$ Book Value Per Share

\section{Institutional Ownership}

Institutional ownership menggunakan indikator persentase jumlah saham yang dimiliki institusi lain atas seluruh saham yang diterbitkan perusahaan. Digunakan oleh penelitian sebelumnya yaitu Fernandez dan Anson (2006) dan Abbasi, et al (2012).

INWN = Jumlah Saham Dimiliki Institusi/Jumlah Seluruh Saham Beredar

\section{ManagerialOwnership}

Variabel ini menggunakan indikator persentase jumlah saham yang dimiliki pihak manajemen atas seluruh saham yang diterbitkan perusahaan. Digunakan oleh penelitian sebelumnya, yaitu: Shen et al. (2006)dan Velnampy (2013).

MGWN = Jumlah Saham Dimiliki Manajemen/ Jumlah Seluruh Saham Beredar

\section{Komposisi Dewan Komisaris Independen}

Proporsi jumlah anggota dewan komisaris dari luar perusahaan terhadap seluruh anggota dewan komisaris, digunakan Garg (2007) dan Pathan et al. (2007).

BIND = Anggota Komisaris Independen / Jumlah Seluruh Angota Komisaris

\section{Ukuran Dewan Direksi dan Komisaris}

Variabel ukuran dewan direksi dan dewan komisaris (BSIZE) ditentukan dengan mengguna-

TABEL 3: Perusahaan Yang Menjalankan Merger-Akuisisi Tahun 2000-2012 di Bursa Efek Indonesia

\begin{tabular}{|c|c|c|c|c|c|}
\hline \multirow{2}{*}{ Tahun } & \multicolumn{2}{|c|}{ Jumlah Perusahaan } & \multirow{2}{*}{ Tahun } & \multicolumn{2}{|c|}{ Jumlah Perusahaan } \\
\hline & Bidder Firm & Target Firm & & Bidder Firm & Target Firm \\
\hline 2000 & 10 Perusahaan & 13 Perusahaan & 2006 & 6 Perusahaan & 6 Perusahaan \\
\hline 2001 & 11 Perusahaan & 16 Perusahaan & 2007 & 2 Perusahaan & 3 Perusahaan \\
\hline 2002 & 9 Perusahaan & 10 Perusahaan & 2008 & 11 Perusahaan & 11 Perusahaan \\
\hline 2003 & 4 Perusahaan & 5 Perusahaan & 2009 & 5 Perusahaan & 5 Perusahaan \\
\hline 2004 & 7 Perusahaan & 8 Perusahaan & 2011 & 1 Perusahaan & 1 Perusahaan \\
\hline 2005 & 6 Perusahaan & 9 Perusahaan & 2012 & 0 Perusahaan & 0 Perusahaan \\
\hline Jumlah & 47 Perusahaan & 61 Perusahaan & Jumlah & 25 Perusahaan & 26 Perusahaan \\
\hline
\end{tabular}

Sumber: Bursa Efek Indonesia periode tahun 2000-2012 


\section{Jurnal Keuangan dan Perbankan | KEUANGAN}

Vol. 20, No.3, September 2016: 382- 394

kan indikator jumlah anggota dewan direksi dan dewan komisaris. Sebagaimana telah digunakan oleh penelitian sebelumnya, yaitu: Garg (2007); Bennedsen et al. (2008); Gill dan John (2012); dan Velnampy (2013).

\section{HASIL}

Hasil pengumpulan data menunjukkan bahwa terdapat159 perusahaan yang menjalankan merger-akuisisi, yang terdiri dari 72 perusahaan pengakuisisi (bidder firm) dan 87 perusahaan yang diakuisisi (target firm). Disajikan pada Tabel 3.

\section{Perbandingan Kinerja Keuangan dan Nilai Perusahaan}

Tabel 4 berikut menyajikan hasil analisis perbandingan kinerja keuangan dan nilai perusahaan antara sebelum dan sesudah merger-akuisisi:

Berdasarkan Tabel 4,secara ringkas dapat dijelaskan bahwa:a). Kinerja keuangan, yaitu ROE berbeda signifikan 3 kali (tahun 2004, 2008, 2009)dan ROI hanya 1 kali (tahun 2006); b). Nilai Perusahaan, yaitu PER berbeda signifikan 4 kali(tahun 2000, 2000, 2001, 2006) dan PBV 3 kali (tahun, 2001, 2004 dan 2004); c). Likuiditas, yaitu CRR dan CHR masing-masing berbeda 1 kali,yaitu tahun 2000 dan 2006; d). DAR dan DER tidak berbeda signifikan; e). Tahun-tahun yang tidak tercantum pada Tabel 4,menunjukkan tidak ada variabel yang berbeda secara signifikan.

Berdasarkan hasil pengujian wilcoxon signed ranks, maka $\mathrm{H}-1.1$ yang menyatakan bahwa capaian kinerja keuangan (ROE) lebih sering berbeda secara singnifikan setelah perusahaan menjalankan program merger-akuisisi, diterima. Demikian pula H-1.2 yang menyatakan bahwa capaian nilai perusahaan(PER) lebih sering berbeda secara singnifikan setelah perusahaan menjalankan program merger-akuisisi, diterima.

\section{Daftar Perusahaan Yang Mencapai Sinergis Menjalalankan Merger-Akuisisi}

Variabel yang sering berbeda secara signifikan adalah profitabilitas dan nilai perusahaan, sehingga untuk menentukan keberhasilan mergerakuisisi didasarkan padacapaian kedua variabel tersebut. Terbatasnya informasi tentang target firm, karena hampir seluruh target firmtidak go publicdi Bursa Efek Indonesia, maka faktor-faktor yang menentukan keberhasilan dan gagalnya mergerakuisisi yang dijalankan perusahaan ditetapkan dengan cara menganalisisi kondisi dari bidder firm.

Tabel 4: Ringkasan Hasil Wilcoxon Signed Ranks Test

\begin{tabular}{|c|c|c|c|c|c|c|c|c|c|c|c|c|c|c|c|c|}
\hline Thn & VAR & SIG & VAR & SIG & VAR & SIG & VAR & SIG & VAR & SIG & VAR & SIG & VAR & SIG & VAR & SIG \\
\hline 2000 & CHR t2 & 0,015 & PER t2 & 0,09 & PER t1 & 0,013 & PBV t1 & 0,047 & & & & & & & & \\
\hline 2001 & & & & & PER t1 & 0,050 & & & & & & & & & & \\
\hline 2004 & & & & & & & PBV t1 & 0,018 & ROE t1 & 0,018 & PBV t2 & 0,028 & & & & \\
\hline 2006 & & & & & PER t1 & 0,046 & & & & & & & CRR t2 & 0,046 & ROI t2 & 0,028 \\
\hline Thn & VAR & SIG & VAR & SIG & VAR & SIG & VAR & SIG & VAR & SIG & VAR & SIG & VAR & SIG & VAR & SIG \\
\hline 2008 & & & & & & & & & ROE t1 & 0,028 & & & & & & \\
\hline 2009 & & & & & & & & & ROE t1 & 0,049 & & & & & & \\
\hline$\sum$ Sig & 1 & & 1 & & 3 & & 2 & & 3 & & 1 & & 1 & & 1 & \\
\hline
\end{tabular}

Sumber: Hasil analisis menggunakan wilcoxon signed ranks test 


\section{Analisis Penentuan Model Merger-Akuisisi yang Sinergis di Bursa Efek Indonesia \\ Muhamad Umar Mai}

Hasil analisis perbandingan menunjukkan bahwa terdapat 30 bidder firmyang memenuhi kriteria berhasil yaitu minimal 4 kali mencapai kenaikkan profitabilitas dan atau nilai perusahaan, dari 6 kali (seluruh) kemungkinan. Adapun, variabel profitabilitas dan nilai perusahaan yang dijadikan dasar untuk melakukan evalusi adalah return on invesment, return on equity, dan price earnigs ratio. Tabel 5 di bawah ini menyajikan 30 bidder firm yang masuk dalam kategori berhasil atau bersinergi.

Tabel 5: Bidder FirmYang Memenuhi Kriteria Sinergis

\begin{tabular}{|c|c|c|c|c|c|c|c|c|}
\hline \multirow[t]{2}{*}{ THN } & \multirow[t]{2}{*}{ NO } & \multirow{2}{*}{$\begin{array}{c}\text { KODE } \\
\text { PERUSAHAAN }\end{array}$} & \multicolumn{3}{|c|}{$\begin{array}{c}1 \text { THN SEBELUM } \\
\text { DIBANDING1 THN SESUDAH }\end{array}$} & \multicolumn{3}{|c|}{$\begin{array}{c}1 \text { THN SEBELUM } \\
\text { DIBANDING2 THN SESUDAH }\end{array}$} \\
\hline & & & ROI & ROE & PER & ROI & ROE & PER \\
\hline \multirow[t]{5}{*}{2000} & 1 & DYNA & Naik & Naik & Turun & Naik & Naik & Naik \\
\hline & 2 & BATI & Naik & Naik & Turun & Naik & Naik & Turun \\
\hline & 3 & SMAR & Naik & Naik & Turun & Naik & Naik & Naik \\
\hline & 4 & TLKM & Naik & Naik & Naik & Naik & Naik & Turun \\
\hline & 5 & AQUA & Naik & Naik & Naik & Naik & Naik & Naik \\
\hline \multirow[t]{4}{*}{2001} & 6 & INDF & Naik & Naik & Naik & Turun & Turun & Naik \\
\hline & 7 & TOTO & Naik & Naik & Turun & Naik & Naik & Turun \\
\hline & 8 & SMBC & Naik & Naik & Naik & Naik & Naik & Naik \\
\hline & 9 & DVLA & Naik & Naik & Turun & Naik & Naik & Turun \\
\hline \multirow[t]{3}{*}{2002} & 10 & AALI & Naik & Naik & Naik & Naik & Naik & Naik \\
\hline & 11 & SKLT & Naik & Naik & Turun & Naik & Naik & Turun \\
\hline & 12 & SULI & Naik & Naik & Naik & Naik & Naik & Naik \\
\hline \multirow[t]{2}{*}{2003} & 13 & ISAT & Naik & Naik & Naik & Naik & Naik & Naik \\
\hline & 14 & BUMI & Naik & Naik & Naik & Naik & Naik & Naik \\
\hline \multirow[t]{6}{*}{2004} & 15 & MLPL & Naik & Naik & Naik & Turun & Naik & Turun \\
\hline & 16 & PICO & Naik & Naik & Turun & Naik & Naik & Turun \\
\hline & 17 & MPPA & Naik & Naik & Naik & Turun & Naik & Naik \\
\hline & 18 & SDPC & Naik & Naik & Turun & Naik & Naik & Turun \\
\hline & 19 & CPIN & Naik & Naik & Naik & Naik & Naik & Naik \\
\hline & 20 & UNVR & Turun & Naik & Naik & Turun & Naik & Naik \\
\hline \multirow[t]{3}{*}{2005} & 21 & SRSN & Naik & Naik & Turun & Naik & Naik & Turun \\
\hline & 22 & KLBF & Naik & Turun & Naik & Naik & Turun & Naik \\
\hline & 23 & INDP & Naik & Naik & Naik & Naik & Naik & Naik \\
\hline \multirow[t]{3}{*}{2006} & 24 & MITI & Naik & Naik & Naik & Turun & Naik & Naik \\
\hline & 25 & BUMI & Naik & Naik & Naik & Naik & Turun & Turun \\
\hline & 26 & META & Naik & Naik & Turun & Naik & Naik & Turun \\
\hline 2007 & 27 & SMSM & Naik & Naik & Naik & Naik & Naik & Naik \\
\hline 2008 & 28 & PLAS & Naik & Naik & Naik & Naik & Naik & Naik \\
\hline 2009 & 29 & TKIM & Naik & Naik & Naik & Naik & Naik & Naik \\
\hline 2011 & 30 & EMTK & Naik & Naik & Naik & Turun & Naik & Naik \\
\hline
\end{tabular}




\section{PEMBAHASAN}

\section{Analisis Terhadap Faktor-Faktor Keberhasilan Merger-Akuisisi}

Dalam upaya untuk merancang model mergerakuisisi yang sinergis, maka dilakukan analisis terhadap 30 bidder firm yang memenuhi kriteria sinergis yang dite-tapkan. Analisis data ditujukan pada capaian kinerja keuangan dan kondisi mekanis-me corporate governance, untuk 1 dan 2 tahun sebelum merger-akuisisi dijalankan.

Variabel kinerja keuangan terdiri dari: return on invesment(ROI); return on equity (ROE); current ratio (CRR); cash ratio(CHR); debt to equity ratio (DER); dan debt to asset ratio(DAR). Variabel kondisi mekanisme corporate governance terdiri dari: institutional ownership (INWN); board independent (BIND); managerialownership (MGWN); dan Board Size (BSIZE). Hasilpengujian ditunjukkan pada Tabel 6 dan Tabel 7 berikut:

Tabel 6 menunjukkan rata-rata return on invesmentdan return on equity berada di daerah penerimaan $\mathrm{H}_{0}$, ini menunjukkan 30 bidder firmyang bersinergis menjalankan merger-akuisisi mempunyai latar belakang capaian profitabilitas yang baik. Tingkat likuiditas 30 bidder firm sebelum merger-akuisisi,baik untuk current ratio maupun cash ratio berada di bawah rata-rata industri, walaupun hanya current ratio yang signifikan. Hal ini menunjukkan 30 bidder firm tersebut mempunyai latar belakang likuiditas yang tidak baik. Namun, dapat pula diinterpretasikan bahwa para manajer perusahaan lebih memprioritaskan melakukan investasi pada aset-aset produktif guna mengejar profitabilitas, karena ada trade-off antara likuiditas dan profitabilitas.

Tingkat solvabilitas 30 bidder firm sebelum merger-akuisisi, baik untuk debt to asset ratio maupun debt to equity ratiosecara signifikan diatas ratarata industri, ini menunjukkan bahwa perusahaan memiliki latar belakang solvabilitas yang buruk. Kondisi solvabilitas 30 bidder firm tersebut menunjukkan bahwa para manajer cenderung bersifat risk taker, dan risiko yang mungkin dihadapi perusahaan adalah acaman yang berat ketika perekonomian memburuk. Namun, agencytheory menjelaskan bahwa agency problem dapat diatasi dengan melakukan beberapa mekanisme kontrol diantaranya dengan cara meningkatkan pendanaan melalui utang. Utang mewajibkan perusahaan untuk mengembalikan pokok pinjaman dan membayar beban bunga secara periodik, akibatnya manajer akan bekerja keras untuk memenuhi semua kewajibannya (Jensen, 1986 dalam Mai, 2015). Agencytheory selanjutnya menje-laskan bahwa debt merupakan salah satu komponen mekanisme corporate governance.

Tabel 6; Hasil Uji Statistik Kinerja Keuangan Prusahaan

\begin{tabular}{|l|c|c|c|c|l|l|l|l|}
\hline Variabel & $\mathbf{n}$ & $\bar{x}$ & $\mathbf{s}$ & $\boldsymbol{\mu}$ & $\begin{array}{c}\text { Bentuk } \\
\text { Pengujian }\end{array}$ & $\begin{array}{r}\mathbf{t} \text { tabel } \\
\mathbf{a}=\mathbf{0 , 0 5}\end{array}$ & t hitung & \multicolumn{1}{|c|}{ Kesimpulan } \\
\hline ROI & 30 & 0,582 & 1,047 & 0,30 & Dua arah & $+/-2,045$ & 1,467 & $\mathrm{H}_{0}$ diterima \\
\hline ROE & 30 & 0,821 & 1,447 & 0,40 & Dua arah & $+/-2,045$ & 1,585 & $\mathrm{H}_{0}$ diterima \\
\hline CRR & 30 & 1,416 & 0,913 & 2,00 & Dua arah & $+/-2,045$ & $-3,476$ & $\mathrm{H}_{0}$ ditolak \\
\hline CHR & 30 & 0,377 & 0,460 & 0,50 & Dua arah & $+/-2,045$ & $-1,456$ & $\mathrm{H}_{0}$ diterima \\
\hline DER & 30 & 2,254 & 2,567 & 0,90 & Dua arah & $+/-2,045$ & 2,869 & $\mathrm{H}_{0}$ ditolak \\
\hline DAR & 30 & 0,624 & 0,369 & 0,35 & Dua arah & $+/-2,045$ & 4,029 & $\mathrm{H}_{0}$ ditolak \\
\hline
\end{tabular}

Sumber: Hasil analisis data kinerja keuangan 30 bidder firm 


\section{Analisis Penentuan Model Merger-Akuisisi yang Sinergis di Bursa Efek Indonesia}

Muhamad Umar Mai

Tabel 7; Hasil Uji Statistik Kondisi Mekanisme Corporate Governance

\begin{tabular}{|l|c|c|c|c|c|c|c|l|}
\hline Variabel & $\mathbf{n}$ & $\bar{x}$ & $\mathbf{s}$ & $\boldsymbol{\mu}$ & $\begin{array}{c}\text { Bentuk } \\
\text { Pengujian }\end{array}$ & $\begin{array}{c}\mathbf{t} \text { tabel } \mathbf{\alpha}= \\
\mathbf{0 , 0 5}\end{array}$ & $\mathbf{t}$ hitung & \multicolumn{1}{|c|}{ Kesimpulan } \\
\hline INWN & 30 & 0,697 & 0,173 & 0,50 & Dua arah & $+/-2,045$ & 6,156 & $\mathrm{H}_{0}$ ditolak \\
\hline BIND & 30 & 0,346 & 0,020 & 0,30 & Dua arah & $+/-2,045$ & 12,432 & $\mathrm{H}_{0}$ ditolak \\
\hline MGWN & 30 & 0,019 & 0,055 & 0,05 & Dua arah & $+/-2,045$ & $-3,083$ & $\mathrm{H}_{0}$ diterima \\
\hline BSIZE & 30 & 5,333 & 2,496 & 6,00 & Dua arah & $+/-2,045$ & $-1,456$ & $\mathrm{H}_{0}$ diterima \\
\hline
\end{tabular}

Sumber: Hasil analisis data mekanisme corporate governance 30 bidder firm

Tabel 7 menunjukkan bahwa rata-rata nilai INWN berada di daerah penolakan $\mathrm{H}_{0}$, ini menunjukkan bahwa saham dari 30 bidder firm dimiliki oleh institusi lain lebih dari $50 \%$. Sebagimana telah dikemukan bahwa institutional ownership yang lebih besar dari 50\% menunjukkan kekuatan para investor dalam memonitor kinerja manajemen (Bathala, et al., 1994; dalam Darmono dan Bachtiar, 2015). Nilai BIND berada di daerah penolakan $\mathrm{H}_{0^{\prime}}$ artinya secara signifikan 30 bidder firm memiliki anggota komisaris independen lebih dari $30 \%$. Kondisi ini menunjukkan 30 bidder firm telah sejalan dengan keputusan Direksi PT Bursa Efek Jakarta No. Kep339,/BEJ/07-2001 butir C tentangboards governance. Keputusan tersebut menyatakan bahwa untuk mencapai good corporate governance maka jumlah anggota dewan komisaris dan/dewan direksi independen sekurang-kurangnya 30\% dari seluruh anggota dewan.

Nilai MGWN berada di daerah penerimaan $\mathrm{H}_{0^{\prime}}$ ini menunjukkan bahwa jumlah saham dari 30 bidder firmyang dimiliki oleh pihak manajemen kurang dari 5\%. Sejalan dengan temuan Morck et al. (1989) dalam Pakaryaningsih (2008) yang menyatakan bahwa hubungan positif antara kepemilikan manajerial dan capaian kinerja keuangan perusahaan akan terjadi pada level kepemilikan $0 \%$ $5 \%$ dan negatif pada level $5 \%-25 \%$. Nilai BSIZE berada di daerah penerimaan $\mathrm{H}_{0^{\prime}}$, hal ini menunjukkan bahwa rata-rata jumlah anggota dewan komisaris yang dimiliki oleh 30 bidder firm sekitar 6 orang. Kondisi ini sejalan dengan hasil penelitian Grag
(2007) yang membuktikan bahwa ukuran board of commissioners yang ideal bagi perusahaan adalah sekitar 6 orang.

\section{Model Merger-Akuisisi Yang Sinergis}

Berdasarkan pada hasil analisisdata selanjutnya dapat dirancangsuatu model merger-akuisisi yang diprediksi akan mampu menciptakan sinergis, dalam bentuk piktografik. Model tersebut dikemukakan pada Gambar 3 berikut:

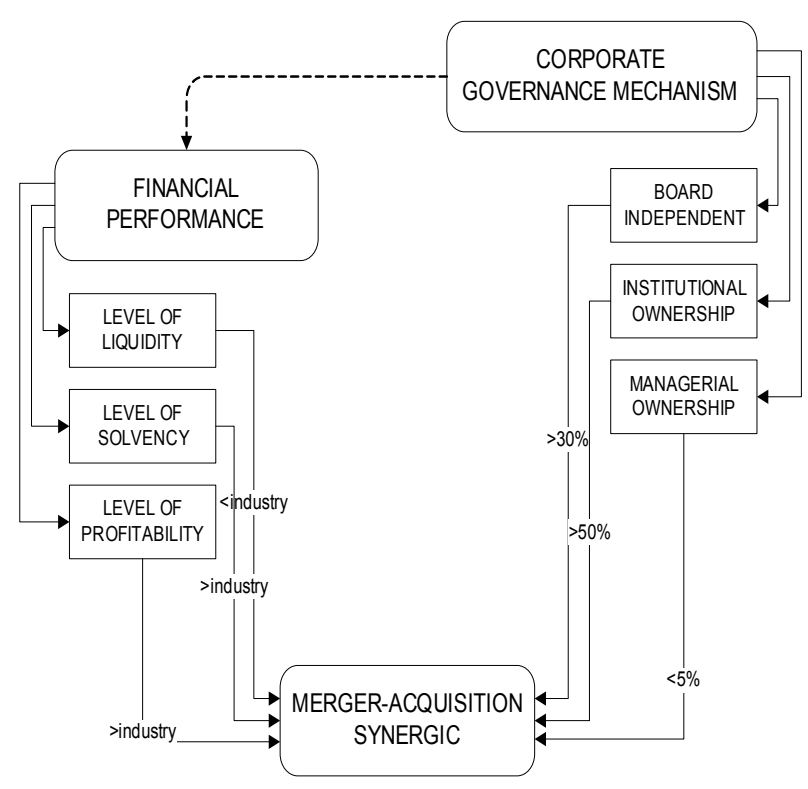

Gambar 3: Model Merger-Akuisisi yang Sinergis Sumber: dirancang berdasarkan hasil penelitian 


\section{Jurnal Keuangan dan Perbankan | KEUANGAN}

Vol. 20, No.3, September 2016: 382- 394

\section{KESIMPULAN}

Mengacu pada hasil analisis, berikut adalah beberapa simpulan yang dapat ditarik:

1). Hasil pengujian terhadap kinerja keuangan dan nilai perusahaan sebelum dan sesudah program merger-akuisisi di jalankan perusahaan, menunjukkan bahwa variabel ROE, ROI dan PERsering berbeda secara singnifikan;

2). Terbatasnya informasi mengenai kondisitarget firm, maka faktor-faktor penentu keberhasilan merger-akuisisi diarahkan pada kondisi bidder firm. Keberhasilan merger-akuisisi ditentukan oleh capaian ROE, ROI dan PER, dan berdasarkan hal tersebut diperoleh 30 bidder firm yang memenuhi kriteria bersinergis.

3). Model merger-akuisisi yang sinergis dirancang dengan menganalisis capaian kinerja keuangan dan kondisimekanisme corporate governance30 bidder firm untuk 1 dan 2 tahun sebelum merger-akuisisi dijalankan perusahaan. Hasil analisis menunjukkan 30 bidder firmtersebut memiliki: a). Capaian profitabilitas di atas rata-rata industri; b). Good corporate governancesangat memadai; c). Tingkat likuiditas di bawah ratarata industri dan solvabilitas di atas rata-rata industri.

4). Kondisi likuiditas dan solvabilitas dari 30 bidder firmyang sinergis menjalankan mergerakuisisi menunjukkan bahwa para manajer perusahaan bersifat risk taker, dan salah satu prinsip dalam manajemen keuangan adalah high risk high return.

\section{SARAN}

Bagi pemerintah (pembuat regulasi), bagi perusahaan yang akan menjalankan merger-akuisisi dan bagi para investor. Berikut adalah saran yang dapat dikemuka-kan: Merger-akuisis akan berhasil apabila dijalankan oleh perusahaan-perusahaan dengan latar belakang sebagai berikut: a). Memiliki kinerja keuangan yang baik, terutama capaian profitabilitasnya; b). Memiliki corporate governance yang memadai, terutama dalam struktur kepemilikan saham, struktur keanggotaan dewan komisaris; dan c). Para manajer perusahaan hendaknya bersifat risk taker.

Berdasarkan keterbatasan yang ada pada penelitian ini, rekomendasi untuk penelitian yang akan datang adalah, sebagai berikut: 1). Mengikutsertakan target firm, sehingga tipe mergerakuisisi dapat dianalisis; 2). Menganalisis perusahaan-perusahaan yang mengalami kegagalandalam menjalankan merger-akuisisi, sehingga kondisinya dapat dibandingkan dengan perusahaan-perusahaan yang berhasil; 3). Menambah jangka waktu analisis, sehingga evalusi terhadap hasil mergerakuisisi yang dijalankan perusahaan dapat dilakukan baik untukjangka pendek, menengah maupun untuk jangka panjang.

\section{DAFTAR PUSTAKA}

Abbasi, M., E. Kalantari, dan H. Abbasi.2012. Impact of Corporate GovernanceMechanism on Firm Value:Evidence From The FoodIndustry in Iran. Journal of Basic and Applied Scientific Research. 2(5): $4712-4721$.

Akinbuli, S. F. dan I. Kelilume. 2013. The Effects Of Mergers And Acquisition OnCorporate Growth And Profitability:Evidence From Nigeria. Global Journal Of Business Research. 7 (1): 43-58.

Amanti, L. 2012. Pengaruh Good Corporate Governance terhadap Nilai Perusahaan dengan Pengungkapan Corporate Social Responsibility sebagai Variabel Pemoderasi. Diponegoro Journal of Accounting. 1 (2): 1-9.

Argüden, Y. 2013. A Corporate Governance Model: Building Responsible Boards and Sustainable Business. A Global Corporate Governance Forum Publication. Private Sector Opinion (7): 1-24.

Azeem, A. K. 2011. Merger and Acquisitions (M\&A) in the Indian Banking Sector in Post Liberalization Regime. International Journal of Contemporary Business Studies. 2 (11): 31-45. 


\section{Analisis Penentuan Model Merger-Akuisisi yang Sinergis di Bursa Efek Indonesia}

Muhamad Umar Mai

Bennedsen, M., H. Kongsted dan K. Nielson. 2008. The casual effect of board size in the performance of small and medium-sized firms. Journal of Banking and Finance 32 (4): 1098-1109.

Brealey, R. A., Cooper, I. A., dan E. Kaplanis. 2010. Excess comovement in international equity markets: Evidence from cross-border mergers. Review of Financial Studies. 23 (4): 1718-1740.

Chuang, Y. L, dan T. L. Hung. 2010. The Bigger the Better? Merger and Acquisition Performance of Financial Holding Corporations Empirical Evidence from Taiwan. Emerging Markets Finance \& Trade. 46 (1): 96-107.

Darmono, P. C., dan Y. Bachtiar. 2015. Perspektif Keputusan Investasi Dan Kebijakan Dividen Terhadap Biaya Keagenan, Struktur Modal Dan Nilai Perusahaan. Jurnal Socioscientia7 (1): 123-130.

Evaruth. 2010. Bentuk-bentuk Badan Usaha. http:// evaruth.wordpress. com/2010/10/18/ bentukbentuk badan-usaha. Diakses 4 Januari 2014.

Fernandez, C. dan S. G. Anson. 2006. Does Ownership Structure Affect Firm Performance? Evidence From A Continental-Type Governance System. Corporate Ownership of Control. 3 (2): 27-45.

Garg, A. K. 2007. Influence of Board Size and Independence on Firm Perfonnance: A Study of Indian Companies. Vikalpa: The Journal for Decision Makers 32 (2): 39-60.

Gill, A. dan O. John. 2012. The Impact of Corporate Governance and Financial Leverage on the Value of American Firms. International Research Journal of Finance and Economics91 (2): 46-56.

Idrus, O. dan Irma. 2010. Analisis Kinerja Keuangan Perusahaan Sebelum dan Sesudah Merger dan Akuisisi (Studi Kasus pada Perusahaan yang Terdaftar di BEI). Laporan Penelitian, Universitas Terbuka.

Ikatan Akuntan Indonesia. 2007. Standar Akuntansi Keuangan. Salemba Empat, Jakarta.

Kasmir. 2008. Bank dan Lembaga Keuangan Lainnya. Jakarta, PT Raja Grafindo Persada.

Kayani, A. J., M. B. Javed, A. Majeed, dan A. Shaukat. 2013. Impact Of Merger And Acquisition On Operating Performance And Shareholder Wealth In Pakistan Banking Sector.Interdisciplinary Journal of Contemporary Research In Business. 5 (6): 385-391.
Kumara. N.V, dan M. Satyanarayana. 2013. Comparative Study of Pre and Post Corporate Integration through Mergers and acquisition. International Journal of Business and Management Invention. 2 (3): 3138 .

Lukas, S. dan Basuki. 2014. The Implementation of Good Corporate Governance and its Impact on The Financial Performance of Banking Industry Listed In Idx. SNA 17, Lombok. Universitas Mataram. (2427 Sept 2014): 1-25.

Mai, U.M. 2015. Corporate Governance dan Interdependensi antara Leverage, Profitabilitas Serta Kebijakan Dividen dalam Mencapai Nilai Perusahaan. Jurnal Keuangan dan Perbankan, 19 (2): 213-225.

Moin, A. 2010. Merger Akuisisi dan Divestasi, Yogyakarta: Ekonisia Kampus Fakultas. Ekonomi UII.

Nurviani, N. 2014. Gelombang Merger Melanda: Bangga atau Waspada. http://www.kppu.go.id/id/ blog/2013/01/. Diakses tanggal 2 Mei 2015.

Pakaryaningsih, E. 2008. Peranan Kepemilikan Institusional Terhadap Nilai Perusahaan Dalam Tinjauan Hubungan Non-Linear Kasus Perusahaan Yang Terdaftar Di Bursa Efek Indonesia. BENEFIT Jurnal Manajemen dan Bisnis. 12 (2): 128-137.

Pathan, S., M. Skully, dan J. Wickramanayake. 2007. Board Size, Independence and Performance: An Analysis of Thai Banks. Asia-Pacific Financial Markets. 4 (3): 211-227.

Rani. N, S. S. Yadav, dan P. K. Jain. 2013. Post-M\&A Operating Performance of Indian Acquiring Firms: A Du Pont Analysis. International Journal of Economics and Finance. 5 (8): 65-73.

Rangkuti, R. K. 2012. The Wilcoxon Matched Pairs Signed Ranks Test. Makalah. Fakultas Keguruan dan Ilmu Pendidikan. Universitas Islam Sumatra Utara. Medan.

Shen, M. J., C. C. Hsu, dan M. C. Chen. 2006. A Study of Ownership Structures and Firm Values Under Corporate Governance - The Case of Listed and OTC Companies in Taiwan's Finance Industry. The Journal of American Academy of Business, Cambridge. 8 (1): 184-191.

Shukla, A., dan M. Gekara. 2010. Effects of Multinational Mergers and Acquisitions on Shareholders' 


\section{Jurnal Keuangan dan Perbankan | KEUANGAN}

Vol. 20, No.3, September 2016: 382- 394

Wealth and Corporate Performance. IUP Journal of Accounting Research and Audit Practices. 9(2): 44-62.

Stella. 2009. Pengaruh Price To Earning Ratio, Debt Too Equity Ratio, Return On Asset, dan Price To Book Value Terhadap Harga Pasar Saham. Jurnal Bisnis Dan Akuntansi. 11(2): 97-196.

Syanas, K.L. 2008. Analisis Determinan Price Earning Ratio pada Perusahaan Perbankan yang terdaftar di BEI. Jurnal Bisnis dan Manajemen. 8 (2): 57- 64.

Trivedi, A., J. Desai, dan N. A. Joshi. 2013. A Study on Mergers \& Acquisitions in Oil \& Gas Sector in India and Their Impact on the Operating Performance and Shareholders' Wealth. Working Paper Series No.CPI/MBA,(2): 1-30.

Velnampy, T. 2013. Corporate Governance and Firm Performance: A Study of Sri Lankan Manufacturing Companies. Journal of Economics and Sustainable Development 4 (3): 228-235.
Weber, Y., T. Shlomo, dan A. Reichel. 2011. A Model of the Influence of Culture on Integration Approaches and International Mergers and Acquisitions Performance. Intnational Studies of Mgt. \& Org.41 (924).

Widodo. 2012. Merger dan Akuisisi, perkembangan dan kritisinya.http: / setiyowidodo.blogspot.com/ merger-dan-akuisisi-perkembangan-. Diakses tanggal 2 Januari 2014.

Wijaya, A. 2013. Pengaruh Informasi Merger Terhadap Harga Saham Dan Volume Perdagangan Pada Perusahaan Yang Terdaftar Di Bursa Efek Indonesia. https://qinkagung.files.wordpress.com/ .../artikel-ai-agung-wijaya-121010.Diakses $20 \mathrm{Mei}$ 2014. 